\title{
Strategy Formulation to Develop IT-Entrepreneurship Innovation for College Students
}

\author{
Endang Supriyati ${ }^{1}$, Mohammad Iqbal ${ }^{2}$, Tutik Khotimah ${ }^{3}$ \\ \{endang.supriyati@umk.ac.id ${ }^{1}$, mohammad.iqbal@umk.ac.id², tutik.khotimah@umk.ac.id ${ }^{3}$ \} \\ Informatic Department, Muria Kudus University, Kudus - Indonesia, 53529 ${ }^{13}$, Electric Engineering \\ Department Muria Kudus University, Kudus - Indonesia, 53529²
}

\begin{abstract}
Universities have great potential in generating new startups in information technology. One of the problems is the difficulty of looking for a creative, innovative and financial benefit of IT business. Generally, they only understand that they are engaged in the IT business known as "Digital Business". One of the keys to succeed in running a business is to know clearly the type and field of business that is occupied. The writers develop strategy formulas to generate startup in IT. The main strategy formulation is at the stage of innovation development. This stage is conducted by combining several components namely IT components, digital product categories, industry classification and business trends. This stage is allowed extensively to create and innovate. Through this research, the writers examine and test the strategy formulation by looking at some innovation efforts in the field of IT produced by students.
\end{abstract}

Keywords: strategy formulation, creative, innovation, digital business, startup, entrepreneurship.

\section{Introduction}

Entrepreneurship, in the modern open economy, is essential for economic growth. For reasons of globalization and revolution in the field of information technology that affect economic growth. The entrepreneur is an individual or organization who runs a business. Entrepreneurship is the art of becoming an entrepreneur. Entrepreneurs must be able to turn ideas into action. This requires creativity, innovation, and risk-taking, in addition to competence to plan and manage projects to achieve goals [1] Developing entrepreneurial attitudes is a complex process, involving the important goals of education and cooperation of all parties involved. Information and Communication Technology (ICT) affects entrepreneurship education as new technologies support the development of new entrepreneurial forms [2].

The feature of information technology capable of being implemented in all areas has the potential to make it difficult for students to find suitable areas of work. One of the problems that happen is the difficulty of looking for a creative, innovative and benefit financial of IT business idea. Creative and innovative IT efforts must be made to compensate for the already stable IT efforts on the market. It takes synchronization between IT and business strategy to seek new breakthroughs in the digital business field. There are many meanings about digital business, but explicitly digital business describes a business ecosystem that will soon 
dominate the way of doing business. Creating a new business is a challenging and complicated task. The risk of failure is very high, but there is always a way to succeed.

Beginner entrepreneurs (start-ups) are usually difficult to translate the business model. So they are difficult to explain the product or service to be made and then how to market. Here it is important to combine back office, marketing and transaction components [3]. Universities need to cultivate entrepreneurial intentions by involving students in campus entrepreneurship because the process of teaching and learning in the classroom is not enough to encourage them to choose entrepreneurship as a career choice [4]. The rapid development of ICT plays an important role in entrepreneurship. Coaching and mentoring greatly affects students to complete projects on time. There is a strong relationship between technological development, inonation, and entrepreneurship. Technopreneurship is not a product but a process of synthesizing in a person's future engineering or organization. Universities need professional employability programs and training to produce strategic thinkers who possess skills to succeed in a rapidly changing global environment [5].

This paper explores and tests the strategy formula for creating new start-ups that have innovations in IT. The structure of this paper is as follows. The first is an introduction, problem statement, study literature, strategy formulation, and implementation.

\section{Problem Statement}

There has been many research on creativity, innovation, entrepreneurship, and technopreneurship. But there are only a few research on strategy formulation to create new start-ups in IT business from college students. Therefore we propose to develop the strategy formulation by combining IT components, digital product categories, industry classification and trends.

\section{Study Literature}

Digital entrepreneurship has revolutionized businesses around the world. The world is working with rapidly evolving computer science so e-business is experiencing rapid growth in the global economy. A business can increase the speed of internationalization compared to other competitors by strengthening the entrepreneurial internationalization experience, innovation ability and marketing ability [6][7][8] Business in the world today is also characterized by the dynamics and high complexity with the globalization of competition and digitization. Competition is increasing as the opening of national borders, multinational expansion, and digital networks. The economic output of a business depends on its innovative capability. As a result of globalization, many companies must develop more products in a short time. Product innovation must have protection by trademark. Companies that protect their new technological developments with patents, trademarks, models or designs will benefit more than their competitors. Innovations without a protective strategy will destroy themselves. [9][10] Innovation is becoming more important for technology companies to secure their position in global competition and generate new growth opportunities for the future. The integration of IT in the production process leads to significant changes especially regarding work and corporate culture [11]. The components of information technology (Table 1.) are hardware, software, data, network, and human. [12] 
Table 1. Component of Information Technology.

\begin{tabular}{|c|c|c|}
\hline Component & Resource & Sub group \\
\hline \multirow[t]{2}{*}{ Hardware } & Machines & physical device (computer, peripherals etc) \\
\hline & Media & all tangibel objects to record data (paper, cd, etc) \\
\hline \multirow[t]{2}{*}{ Software } & Program & a set instruction that causes a computer to perform a particular task \\
\hline & Procedures & set of intruction used by people to complete a task \\
\hline \multirow[t]{2}{*}{ Data } & Databases & a collection of logically related recorded or files \\
\hline & Knowledge Bases & to hold knowledge in variety of form \\
\hline \multirow[t]{2}{*}{ Jaringan } & Communication media & twisted-pair wire, coaxial cable, etc \\
\hline & Network support & people, hardware, software, and data resources \\
\hline \multirow[t]{2}{*}{ People } & End User & people who use an information system \\
\hline & IS Specialists & people who develop and operate information systems \\
\hline
\end{tabular}

The World Intellectual Property Organization (WIPO) has created industry mapping (Table 2.), such as the following table 1 [13]

Table 2. Industry mapping.

\begin{tabular}{|c|c|}
\hline Industri & Sub group \\
\hline \multirow[t]{7}{*}{ Press \& Literature } & *Authours, writers, translator \\
\hline & *News papers \\
\hline & *News agencies \\
\hline & *Book publishing \\
\hline & * Libraries \\
\hline & *Pre-press, printing and pos-press of books \\
\hline & *Press and literature retail \& whole sale (bookstore,etc) \\
\hline \multirow[t]{6}{*}{ Music, Theater, Opera } & *Composers, arragers, choreographers, others \\
\hline & *Printing and publication of music \\
\hline & *Production of recorded music \\
\hline & *Recorded music wholesale and retail (sales and rental) \\
\hline & *Artistic and literary creation and interpretaion \\
\hline & *Staging and related agencies (reservation, tickets, etc) \\
\hline \multirow[t]{3}{*}{ Motion Picture \& Video } & *Writes, directors, actors, etc \\
\hline & *Motion picture and production and distribution \\
\hline & *Motion picture exhibition \\
\hline \multirow[t]{4}{*}{ Radio \& Television } & *National radio and television broadcasting companies \\
\hline & *Other radio and relevision broadcasters \\
\hline & *Independent producers \\
\hline & *Cable TV (systems and channels) \\
\hline \multirow[t]{2}{*}{ Photography } & *Studios and commercial photography \\
\hline & *Photographic agencies and librarries \\
\hline \multirow[t]{3}{*}{ Software \& Databases } & *Programming, development and design, manufacturing \\
\hline & *Wholesale and retail prepackaged \\
\hline & *Software (business program, video games, educational etc) \\
\hline \multirow[t]{5}{*}{ Visual \& Graphic Arts } & * Database processing and publising \\
\hline & *Artist \\
\hline & *Art galleries, wholesale and retail \\
\hline & *Picture framing and other allied services \\
\hline & *Graphic design \\
\hline \multirow[t]{2}{*}{ Advertising } & *Agencies \\
\hline & *Buying Service \\
\hline
\end{tabular}


Digital business is the most sophisticated business today that is expected to continue to grow and the longer it will increase sharply. Digital business is how businesses apply technologies and digital media to enhance the competitiveness of organizations. [14] Digital technology delivers a very complex innovation challenge. Research on technological innovation tends to adopt a macro-level perspective on the object of study, often resulting in high-level descriptions of strategic recommendations [15]. The success of business in the digital field (Figure 1.) is determined by three components: content, customer experience, and platform [16].

\begin{tabular}{|c|c|c|}
\hline \multirow{3}{*}{$\begin{array}{l}\text { Content } \\
\text { What is } \\
\text { consumed? } \\
\text { Experience } \\
\text { How is it } \\
\text { packaged? }\end{array}$} & Information & Product information, price and use details, etc \\
\hline & Product & $\begin{array}{l}\text { Digital products, such as e-books, e-saver accounts, movies, } \\
\text { software }\end{array}$ \\
\hline & $\begin{array}{l}\text { Customer } \\
\text { Experience }\end{array}$ & $\begin{array}{l}\text { Experience can include customer-facing digitized business } \\
\text { processes, community and Cutimer input, expertise for informed } \\
\text { decision making, recommendation, tools and interface }\end{array}$ \\
\hline Platform & Intenal & Other business processes, customer data, technology \\
\hline delivered & External & Proprietary hardware, public networks, partners. \\
\hline
\end{tabular}

Fig. 1. Component of digital business.

Classification of digital products (Table 3.) can be used for the success of digital entrepreneurs. [17] The purpose of this classification is (1) the feature and characteristic of a digital product that can serve as a foundation for determining product and process development platforms, (2) classifications corresponding to product characteristics and product categories can be useful tools for appropriate marketing strategies, most recently developers digital products can identify important features and dimensions of products that deserve more attention and development. A framework for classifying digital products based on product categories and product characteristics. There are three characteristics of digital products namely delivery mode, granularity, and trial ability. Delivery mode is a product delivery mechanism from seller to buyer. This characteristic granularity displays the divisibility of a digital product. Trial ability that not all digital products can be trial by consumers or sellers.

Table 3. Classification of digital products.

\begin{tabular}{|l|l|l|l|}
\hline $\begin{array}{l}\text { Category/ } \\
\text { Characteristic }\end{array}$ & $\begin{array}{l}\text { Tools and } \\
\text { Utilities }\end{array}$ & $\begin{array}{l}\text { Content-based } \\
\text { Digital Products }\end{array}$ & $\begin{array}{l}\text { Online } \\
\text { Services }\end{array}$ \\
\hline Delivery mode & By download & By download & Interview \\
\hline Granularity & Low $^{*}$ & High & Medium \\
\hline Triability & High $*$ & Low & Medium * \\
\hline
\end{tabular}

* relative sense

There are three categories of digital products, that are tools and utilities, content based digital product, and online services. Tools and utilities is this product helps the user to complete the task and special purpose. In general commercial software, shareware, or freeware 
easily download via internet is included in this category. Content-based Digital Products, the value of this type is based on the information content. Online Services, including products that provide access to useful resources such as server connections as well as online utilities, to assist with the completion of specific tasks. And in the end the category of online service is similar to the categories of tools and utilities, which differentiate consumers from being able to actually buy products, consumers can only pay for the information they need.

Table 4. Categories of digital products.

\begin{tabular}{ll}
\hline Category & Example \\
\hline Tools and Utilities & F-Secure for virus scanning and disinfections \\
& Adobe Acrobat for creat and view PDF files \\
& RealPlayer that allows users to listen online boradcast or \\
& audio clips \\
Content-based Digital Products & Wall Street Journal, www.wsj.com \\
& ProQuestDirect, www.proquest.com \\
& Online entertainment (music, video, magazine etc) \\
& Internet telephony (PC-to-Phone, www.webkall.com, \\
& Zeroplus, www.zeroplus.com \\
Online Services & Support services (group system online, www.ventana.com) \\
& Consultant Serach Service (www.searchcon.com) \\
\hline
\end{tabular}

The main factors of student entrepreneurial intentions are personality factors (selfefficacy, risk-taking, needs for achievement, proactive, attitudes toward entrepreneurship, behavioral control and internal locus of control) which can all be developed during a student [18]. Another thing that encourages entrepreneurial interest is the encouragement of academic companies. Academic companies are the kind of companies that have the focus of encouraging, supporting and advancing knowledge. Academic companies have an interest in engaging in a network of universities (colleges) or other academic research institutions, driven by the desire to access university knowledge (e.g. basic university research). In general, academic companies value involvement in a diversified network as a form to create and benefit from opportunities. [19][20]. An important psychological characteristic that affects entrepreneurial behavior is self-employment efficacy. The higher the self-efficacy of selfemployment the higher the success for start-up business. Innovation plays a role in the early phases of entrepreneurship development (3 months - 2 years) [21]. Creativity affects one's entrepreneurial intentions. Creativity is essential to business success, achieving business excellence in an aggressive business world [22].

\section{Strategi Formulation}

The strategy formulation (Figure 2.) for the implementation of entrepreneurship development program each year is divided into 4 (four) phases namely (1) review phase, this phase is used to identify and translate business opportunities. The purpose of this review is to sharpen IT business idea (2) innovation development phase. The second phase is the development of innovation. This phase of the tenant should be able to propose a new business 
idea, by combining several components i.e. IT component, digital business type, and industry classification as a creative effort in the IT field. At this phase field trips are also conducted to incubation canters and prototype facilities. At this phase created awareness of the role of IPR (Intellectual Property Rights) in technology and business development. (3) mentoring and coaching phase [23]. Referring International Coaching Federation (ICF) coaching data increases work performance by up to $70 \%$, improves business management $61 \%$, increases time management by $57 \%$ and increases team effectiveness by $51 \%$. This phase performs software management planning. Tenant will define business goals and targets. Tenant must be responsible for business continuity. The phase of development and implementation of the business is done. and (4) workshop and evaluation phase. In this phase of the workshop is held to increase confidence in decision making, communication skills, interpersonal skills, and realizing their business. Assessment evaluation is the operating profit, the rate of business profit growth, and the business idea are the three basic assessments.

\begin{tabular}{|c|c|c|c|c|}
\hline phase 1: & phase 2: & phase 3: & phase 4: & Post \\
\hline Review & $\begin{array}{c}\text { Innovation } \\
\text { development }\end{array}$ & $\begin{array}{l}\text { Mentoring and } \\
\text { coaching }\end{array}$ & $\begin{array}{l}\text { Workshop } \\
\text { and } \\
\text { evaluation }\end{array}$ & \multirow{4}{*}{$\begin{array}{l}\text { Start up } \\
\text { IT } \\
\text { business }\end{array}$} \\
\hline \multirow{3}{*}{$\begin{array}{c}\text { Identification } \\
\text { of } \\
\text { opportunity } \\
\text { in IT business }\end{array}$} & \begin{tabular}{|l} 
Developing \\
innovation IT \\
business \\
\end{tabular} & Busiiness plan & \multirow{3}{*}{$\begin{array}{l}\text { Workshop } \\
\text { and } \\
\text { evaluation }\end{array}$} & \\
\hline & \begin{tabular}{|l|} 
Internship \\
\end{tabular} & \multirow{2}{*}{\begin{tabular}{|c} 
Build \& \\
implement IT \\
business
\end{tabular}} & & \\
\hline & $\begin{array}{l}\text { Legal } \\
\text { understanding }\end{array}$ & & & \\
\hline
\end{tabular}

Fig. 2. Formula Strategi IT entreprenurship.

In the process of innovation (Figure 3.), development must combine several things namely IT components [13], digital product categories [17], industry classification [12] and business trends. In the category of non-standard digital products as in reference, can be merged product categories, as well as industry and trends. In the strategy formulation phase, it is allowed to create and innovate as widely as possible.

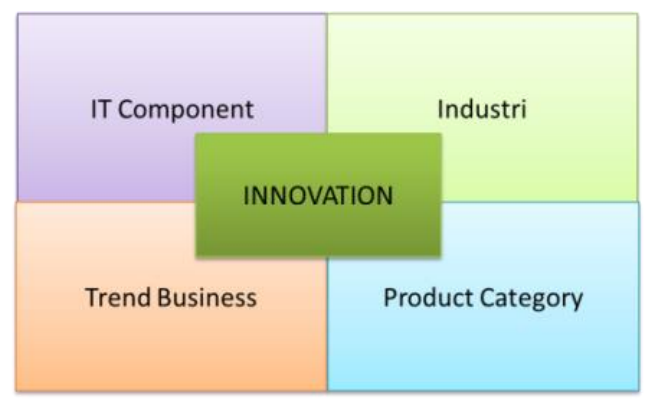

Fig. 3. Innovation to develop start up IT business. 


\section{Implementation}

The Implementation of entrepreneurship development program is as follows:

1. Phase 1 : Review

Review phase is used to identify and translate business opportunities. The purpose of this review is to sharpen IT business ideas. At this phase, tenants propose proposals. Criteria accepted proposal there are three namely: innovation and creativity, impact and legal aspects (possibly HKI).

\section{Phase 2 : Innovation Development}

This phase of the tenant should be able to propose new business ideas, by combining components of IT components, digital business types, and industry classification (figure 3) as creative endeavours in the IT field. At this phase also conducted field trips to incubation centres and prototype facilities. This phase created awareness of the role of IPR in technology and business development. This phase contains the business lessons that should be possessed by a technopreneurship that is (1) Set cashflow Finance, (2) Understanding Trade and Buying Laws, (3) Creating Contracts and Agreements with Prospective Customers, (4) How to communicate with client / vendors, (5) How to recruit employees or staff, (6) How to pay according to the law, (7) And other disciplines that we must learn before building the company.

3. Phase 3 : Mentoring dan coaching

This phase performs software management planning. Tenant will define business goals and targets. Tenant must be responsible for business continuity. IT application development is done in this phase. This phase is the core phase of this program:

a. Product-making phase. This phase begins with product design, product implementation, product testing, product revision

b. After the product is ready to market, tenants set time schedule to release products and features, sort out what features come first, see feedback from users

c. Building portals or websites, activating social media and other communication networks to promote their products and services we have immediately known by the public.

d. Doing public release, networking, looking for investors, looking for clients. Many startups are uprooted, as most startups want to go straight to product creation, without starting to learn preliminary sciences (2nd phase). Because of that, finally when having a product, the product is they do not know what it will be made or it could be the product they produce it already there are others who make it with a stronger source of funds or products they make may not fit the market.

4. Phase 4 : Workshop and Evaluation

a. Workshop

In this workshop, a presentation was held to report that the business has been run. Furthermore, it is also to increase confidence in decision making, communication skills, interpersonal skills, and realizing their business

b. Evaluation

Evaluation of tenant success is done immediately every end of program implementation, by using the following criteria: 
c. Product and Marketing

Product type, product price position on the competitor, product superiority, sales system, improvement effort and sales area.

d. Product Innovation

Types of innovation, innovation benefits, and innovation influences on enterprise development (Table 5.).

Table 5. Example Application of Innovation IT Business.

\begin{tabular}{|c|c|c|c|c|}
\hline Industries & Product Category & IT Component & Trend Bisnis & Application (Innovation) \\
\hline & Content-based Digital & & & \\
\hline Advertising & Products & Data+Software & e-commerce & e-commerce \\
\hline Visual \& Graphic Arts & Tools and Utilities & Data+Software & $\begin{array}{l}\text { Photo Editor } \\
\text { Photography }\end{array}$ & Photo Editor \\
\hline Photography & Tools and Utilities & Data+Software & Digital & Photo Editor \\
\hline Software \& Database & Online service & Network+Peope+Data & e-commerce & $\begin{array}{l}\text { Social network analysis services } \\
\text { (exp. SEO) }\end{array}$ \\
\hline Software \& Database & Online service & Network+Peope+Data & Mobile & Application to search homestay \\
\hline & Content-based Digital & & & $\begin{array}{l}\text { Appication to search path to ICU } \\
\text { hospital }\end{array}$ \\
\hline Software \& Database & Products & Network+Peope+Data & Moblie & $\begin{array}{l}\text { hospital } \\
\text { Plagiarism source program }\end{array}$ \\
\hline Software \& Database & Tools and Utilities & Data+Software & security & cekker \\
\hline
\end{tabular}

This is an application for searching Accident \& Emergency Department (Unit Gawat Darurat - UGD) (figure 4.a-d). A location-based service is an information service that is accessible to mobile devices and is able to show geographical position of the mobile device. The application of Accident \& Emergency Department and Community Health Clinic, is an application to search the hospital and health center by using the name of hospital in accordance with the user or public using mobile android. This application helps people provide general information about hospitals and health centers and their location to the community.

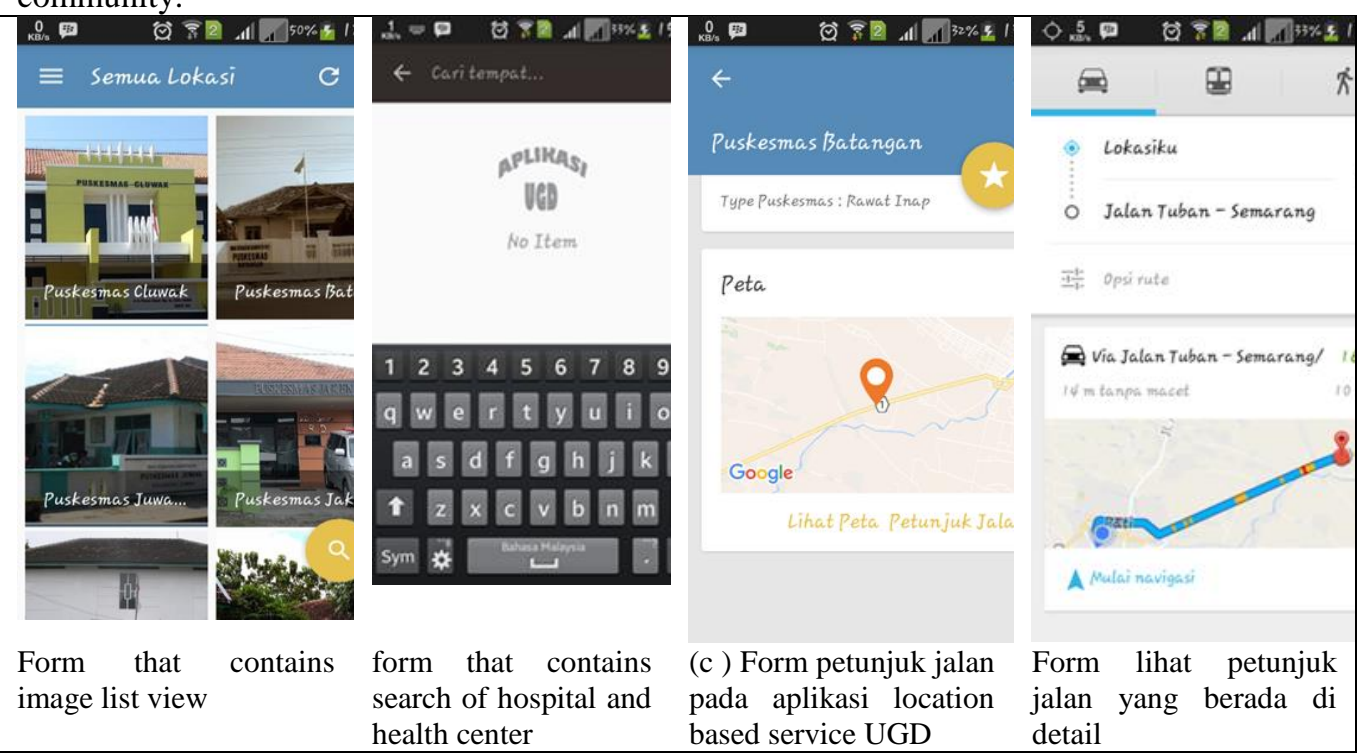

Fig. 4. Application for searching Accident \& Emergency Department. 


\section{Acknowledgment}

This research is funded by the Directorate General of Higher Education through Entrepreneurship Development Program (PPK) 2018 -2020.

\section{Reference}

[1] D. A. Shepherd, "Educating Entrepreneurship Students About Emotion and Learning From Failure," Acad. Manag. Learn. Educ., vol. 3, no. 3, pp. 274-287, 2004.

[2] I. Hamburg, S. Bucksch, and E. O. Brien, "ICT - based Approaches for Entrepreneurship Education,” Tenth Int. Conf. Internet Web Appl. Serv., pp. 88-91, 2015.

[3] C. Standing and J. Mattsson, “"Fake it until you make it': business model conceptualization in digital entrepreneurship,” J. Strateg. Mark., vol. 26, no. 5, pp. 385-399, Jul. 2018.

[4] S. C. Mat, S. M. Maat, and N. Mohd, "A descriptive analysis on entrepreneurial intention among engineering technology students," Asian Soc. Sci., vol. 11, no. 24, pp. 286-292, 2015.

[5] R. A. Fowosire, O. Y. Idris, and O. Elijah, "Technopreneurship: A View of Technology, Innovations and Entrepreneurship,” Glob. J. Res. Eng., vol. 17, no. 7, pp. 41-46, 2017.

[6] B. Ziyae, S. M. Sajadi, and M. H. Mobaraki, "The deployment and internationalization speed of e-business in the digital entrepreneurship era," J. Glob. Entrep. Res., vol. 4, no. 1, p. 15, 2014.

[7] M. S. Prince Machado, G. C. Tenorio Sepúlveda, and M. S. Ramirez Montoya, "Educational innovation and digital competencies: the case of OER in a private Venezuelan university," Int. J. Educ. Technol. High. Educ., vol. 13, no. 1, pp. 1-10, 2016.

[8] W. Li, W. Du, and J. Yin, "Digital entrepreneurship ecosystem as a new form of organizing: the case of Zhongguancun," Front. Bus. Res. China, vol. 11, no. 1, p. 5, 2017.

[9] D. J. Teece and G. Linden, "Business models, value capture, and the digital enterprise," J. Organ. Des., vol. 6, no. 1, p. 8, 2017.

[10] O. A. El Sawy and F. Pereira, Business Modelling in the Dynamic Digital Space An Ecosystem Approach. 2013.

[11] V. Ignat, "Digitalization and the global technology trends," IOP Conf. Ser. Mater. Sci. Eng., vol. 227 , no. $1,2017$.

[12] J. A. O'Brien and G. M. Marakas, Management Information System, vol. 172, no. November 2014. 2005.

[13] B. Pratama, "Indonesian legal framework to support innovation sustainability," IOP Conf. Ser. Earth Environ. Sci., 2018.

[14] K. S. Sia, C. Soh, and P. Weill, "How DBS Bank Pursued a Digital Business Strategy," MIS Q. Exec., vol. 15, no. 2, pp. 105-121, 2016.

[15] D. Nylén and J. Holmström, "Digital innovation strategy: A framework for diagnosing and improving digital product and service innovation," Bus. Horiz., vol. 58, no. 1, pp. 57-67, 2015.

[16] P. Weill and S. Woerner, "Optimizing Your Digital Business Model," MIT Sloan Manag. Rev., vol. 54, no. 3, pp. 71-78, 2013.

[17] K. L. Hui and P. Y. K. Chau, "Classifying digital products.," Commun. ACM, vol. 45, no. 6, pp. 73-79, 2002.

[18] R. Remeikiene, G. Startiene, and D. Dumciuviene, "Explaining Entrepreneurial Intention of University Students: the Role of Entrepreneurial Education,” Manag. Knowl. Learn. Int. Conf. 2013, pp. 299-307, 2013.

[19] D. F. J. Campbell and E. G. Carayannis, "The academic firm: a new design and redesign proposition for entrepreneurship in innovation-driven knowledge economy,” J. Innov. Entrep., vol. 5, no. 1 , p. 12,2016

[20] V. Fernández-Pérez, P. E. Alonso-Galicia, L. Rodríquez-Ariza, and M. del M. FuentesFuentes, "Professional and personal social networks: A bridge to entrepreneurship for academics?," Eur. Manag. J., vol. 33, no. 1, pp. 37-47, 2015.

[21] A. Dessyana, B. Prihatin, and D. Riyanti, "The Influence of Innovation and Entrepreneurial Self-Efficacy to Digital Startup Success,” Int. Res. J. Bus. Stud., vol. 10, no. 1, pp. 57-68, 2017. 
[22] H. Emrie Rosly, J. Junid, N. Faizah Mohd Lajin, and H. Loh Rahim, "The Relationship of Creativity and Technopreneurship Intention,” Int. Acad. Res. J. Soc. Sci. Int. Acad. Res. J. Soc. Sci. Int. Acad. Res. J. Soc. Sci., vol. 1, no. 11, pp. 8-15, 2015.

[23] C. Coe, A. Zehnder, and D. C. Kinlaw, Coaching for commitment: Achieving superior performance from individuals and teams. Pfeiffer, 2008. 